ISSN: 2091-0657 (Print); 2091-0673 (Online)

Open Access

\title{
Modern technologies in the management of diabetes
}

\author{
Anbreen Iqbal ${ }^{1}$, Muhammad Asif ${ }^{2}$, Muhammad Imran Qadir ${ }^{1}$ \\ ${ }^{1}$ Institute of Molecular Biology \& Biotechnology, Bahauddin Zakariya University, Multan, Pakistan \\ ${ }^{2}$ Department of Clinical Medicine \& Surgery, University of Veterinary and Animal Sciences, Lahore, \\ Pakistan
}

\begin{tabular}{l}
\hline Correspondence \\
Dr. Muhammad Imran Qadir \\
Department of Clinical Medicine \\
\& Surgery, University of \\
Veterinary and Animal Sciences, \\
Lahore, Pakistan \\
Email: \\
mrimranqadir@hotmail.com \\
DOI: http://dx.doi.org/10.3126/ \\
jcmsn.v13i2.16921 \\
Article received: $11^{\text {th }}$ March \\
2016 \\
Article accepted: $15^{\text {th }}$ June 2017
\end{tabular}

\begin{abstract}
Diabetes is not one disease but rather is a heterogeneous group of syndromes characterized by an elevation of fasting blood glucose caused by a relative or absolute deficiency in insulin. The two main types of diabetes occur, type-1 is insulin dependent diabetes mellitus and type- 2 is non insulin dependent diabetes mellitus. In type-1 body does not produce insulin and about $10 \%$ of all diabetic patients are affected. In type- 2 diabetes imbalance of insulin and glucose occur and there are about $90 \%$ cases for type- 2 diabetes. Gestational diabetes is also a type of diabetes and it is found mostly in women's who are pregnant later such women's are affected with type- 2 diabetes and about $40 \%$ cases are studied. Different countries are affected at high level from diabetes. For the treatment of diabetes different techniques like insulin injection, oral vaccination, pancreas transplantation, transplantation of encapsulated islet cells, gene therapy technique and islet cell transplantation are used. All techniques have some advantages and disadvantages, but the encapsulated islet cell transplantation technique is promising with minimum complications.
\end{abstract}

Key words: Beta cells; diabetes; encapsulated islet cells; gene therapy; insulin; oral vaccination; pancreas

Citation: Iqbal A, Asif M, Qadir MI. Modern technologies in the management of diabetes. JCMS Nepal. 2017;13(2):296-301.

\section{INTRODUCTION}

Diabetes is not one disease but rather is a heterogeneous group of syndromes characterized by an elevation of fasting blood glucose caused by a relative or absolute deficiency in insulin. ${ }^{1}$ For our metabolic functions glucose is the good source of energy. ${ }^{2}$ Diabetes is a condition characterized by deficient insulin production or peripheral insulin resistance with consequent hyperglcemia.3 Symptoms of diabetes include vision loss, frequent urination, thirst, weight loss, extreme hunger, feeling tiredness, slow healing of sores, infections more than usual, very dry skin and male sexual dysfunction. $^{4}$

About 10 million people are affected from diabetes in the United States. ${ }^{5}$ In Pakistan approximately 7.1 million patients are affected from diabetes and it is an alarming situation for Pakistan. It is estimated that in 2030 Pakistan diabetic patients will be ranked $10^{\text {th }}$ in the world. ${ }^{6}$ Onset of type $1 \mathrm{DM}$ is usually in childhood or adolescence. It occurs due to autoimmune destruction of pancreatic beta cells often triggered by a viral infection. Type-1 DM can also occur later in adulthood. Type-2 DM accounts for more than $90 \%$ of total diabetic cases worldwide. ${ }^{7}$ It is characterized by peripheral insulin resistance and is strongly associated with advancing age, obesity, positive family history and physical inactivity ${ }^{8,9}$ Diabetic patients need to be physically active, eat healthily, and test their blood glucose. ${ }^{10}$ Smoking has bad effect on heart so the patients of diabetes should avoid from it. ${ }^{11}$ Hypoglycemia in which blood glucose becomes low and it also have a serious effect on the patient. Hyperglycemia in which blood glucose is too high has serious effects on patient's health.

Gestational diabetes occurs during pregnancy about $2-5 \%$ and when pregnancy is over it disappears. ${ }^{12}$ Obesity is also the main cause of diabetes. Such women later develop Type-2 diabetes that has 


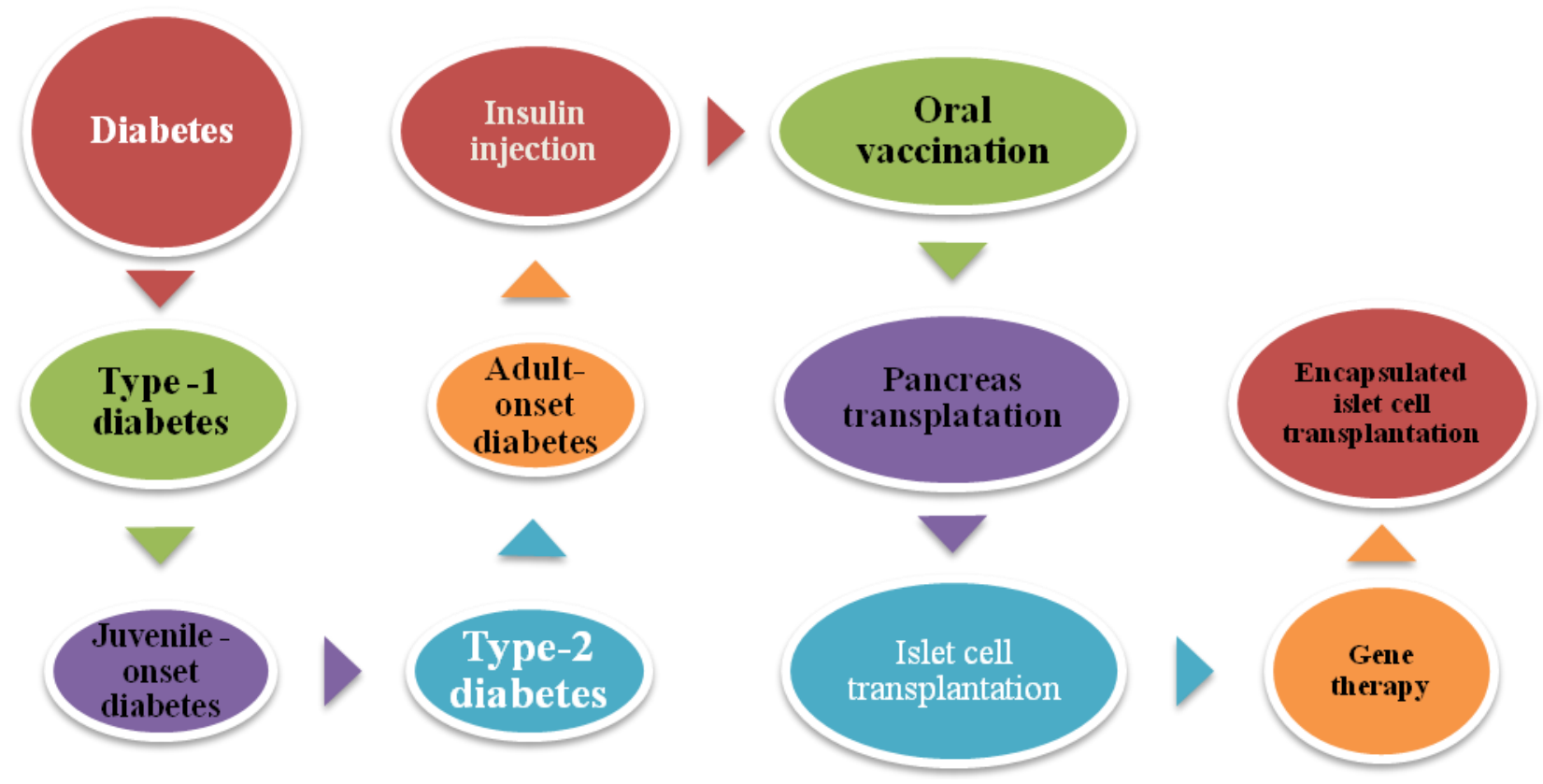

Fig 1: Brief overview of Diabetes

gestational diabetes and about $40 \%$ cases are studied of affected women with a history of gestational diabetes. Recently more advanced techniques have been developed and are being used for the treatment of diabetes. Some major techniques viz insulin injection, oral vaccination, pancreas transplantation, beta cell transplantation, gene therapy technique and encapsulated islet cell transplantation are used. Insulin is the most commonly used method for the treatment of both types of diabetes. Different types of patient care according to their glucose level use different types of insulin injections. The diabetic patient's used mostly two to three injections per day to control their glucose level according to their meals timing. But it is a painful process and common sites for insulin injection are lower abdomen and upper arm, so in public places people show embarrassment. ${ }^{13}$ Oral vaccination is also used for the treatment of diabetes. It require repeated dosages but it's cheap way to treat diabetes. Other technique for the treatment of severe form of diabetes is pancreas transplantation. In this technique patient cannot use insulin injection because his own body produces insulin. But the immune system attack the new pancreas because it is a foreign thing, to solve this problem immunosuppressive drugs are used but it lowers the patient's immune system ability to combat with serious types of injections. ${ }^{14}$ Islet cell transplantation is the modern technique to control diabetes allo and auto transplantation is used for this purpose. Both types of islet cell transplantation main aim are to insert beta cells from the donor or from the pancreas of its own body which then produce normally insulin. But immunosuppressive drugs are used to enhance the life of beta cells which has many drawbacks. Gene therapy technique is also used in which healthy beta cells are inserted into the patient's body but immunosuppressive drugs are also required to be taken by the patient. To remove this problem new technique called encapsulated islet cell transplantation is used. This technique does not require therapy with immunosuppressive drugs because the islet cells are protected in a capsule which does not allow white blood cells of immune system to attack the cells. ${ }^{15}$

Figure 1 shows the brief overview of diabetes. The different techniques for the control of diabetes are discussed in detail in following sections.

\section{Insulin injection}

Insulin is recommended for both type 1 and type 2 DM, that's why these terms are not used these days. According to the meals timing insulin will be delivered to the patient of diabetes. The patient's diagnosed with type-1 diabetes first start two insulin injections per day. and they are two different 
types of insulin after that they start three to four injections of different types according to their glucose levels requirement. ${ }^{16}$ It has been reported that per day two to three injections of insulin gives better results to manage glucose levels of patient with minimum side effects of kidney, nerve and eye damage.

The blood glucose level is affected by the place of insulin injection in the body. When insulin is injected at different sites its speed is also different. Insulin shots work very fast when it is given in the abdomen. From the upper arms insulin enters slowly in the blood and from the buttocks and thighs even more slowly. But subcutaneous insulin injections are more popular recently for type-1 diabetic patients. Insulin injection has some benefits and some drawbacks. For type- 1 diabetic patient's insulin injections show improved quality of life and convenience. It is studied that about $20 \%$ of patients do not use insulin injections due to some reasons like embarrassment or pain and common sites are the lower abdomen and upper arm. ${ }^{17,18}$

\section{Oral vaccination}

Mucosal induced immunization is used for treating different diseases which are caused due to immune response against non-self or self antigens. Oral vaccination is used to suppress the autoimmune and allergic disorders and type- 1 diabetes is an autoimmune disease. The diseases controlled by oral vaccination must require repeated dosage The protection of oral vaccines must be necessary because they passed from the adverse environmental conditions of the stomach. The better way is that for the delivery of oral vaccines transgenic plants must be used it is safe, inexpensive and multicomponent way to treat diabetes.

\section{Pancreas transplantation}

The pancreas is the main organ for insulin production which is present near the stomach. In type-1 diabetes the pancreas is unable to produce insulin so pancreas transplantation is used for such type of patients. Mostly part or all of a new pancreas of donor is surgically implanted into the patient. And the old pancreas is left in the body alone; which still makes enzymes which digest the food but it cannot make insulin. Mostly organs are donated by someone who will be died but he has decided plan for organ donation. When patient receives a new kidney pancreas transplantation is done during this time. The pancreas transplantation also has some benefits and some drawbacks. But pancreas transplantation surgery is risky. Each patient needs to be weighing the potential risks and benefits. There are following benefits of Pancreas Transplantation.

The patient may be able to maintain a blood glucose level normal without taking insulin. After pancreas transplantation many of the side effects related to diabetes are delayed or prevented. ${ }^{19}$ Mostly people with nerve damage show some improvement after pancreas transplantation without getting much worse. The drawbacks of Pancreas transplantation are following. The body of the patient treats the new pancreas as antigen and the antibodies of immune system attacks the pancreas which is transplanted. So to suppress the immune system transplant patients may take powerful drugs which are immunosuppressant and in this way they prevent the rejection problem of the new pancreas. But these drugs that suppress the immune system cause problems like lower resistance to other harmful diseases, like bacterial and viral infections and cancer. ${ }^{20}$

\section{Islet cell transplantation}

It is an advanced technique to control diabetes. Islet are the small clusters of cells which are scattered throughout the pancreas and they are also called islet of Langerhans. ${ }^{21}$ Islet of Langerhans contains many types of cells and beta cells are one of them that are responsible for the production of the hormone insulin, when the level of blood sugar rises after eating food then into the blood stream pancreas secretes insulin to digest the food. Glucose is absorbed from the blood stream and then it is used as energy form. Pancreatic islet cell transplantation has following two main types' pancreatic islet allo-transplantation and pancreatic islet auto-transplantation. In allo transplantation the donor islet cells are obtained then after purification and processing these islet cells are transferred into the patient's body. With an average of 400,000 to 500,000 islets the patient's mostly use two infusions per infusion. After transplantation of islet cells the beta cells which are present in the islet cells start producing insulin. The type- 1 diabetes patient's use this islet allo-transplantation because there level of blood glucose is not in controlled. In the liver the blood is supplied by the portal vein and it is one of the major veins for the supplying of 
blood. Through the catheter the islet cells are pushed slowly into the liver. To improve the functioning and to reduce the need for insulin injections patient's mostly use two or more than two transplantation. Pancreas islet autotransplantation is another procedure of islet cell transplantation. This procedure is used for those patients whose pancreas is totally damaged and other treatments are also not possible. The patients with type-1 diabetes do not use this islet auto transplantation procedure. In this procedure first anesthesia is given to the patient then the surgeon removes his pancreas after extraction and purification of islets from the pancreas they are infused within hours into the patient's body. After transplantation the insulin is produced by islet cells. But the growth of new blood vessels and islet cells is slow during this time the patient must use insulin injections to control their glucose levels. Different types of medicines are used by patient before and after transplantation to minimize the autoimmune attack and to enhance the life of beta cells. Liver is used for the transplantation of islet cells now researchers are investigating other sites for infusion to improve this procedure. ${ }^{22}$ Through this pancreas islet allo-transplantation the glucose level of patient is improved, insulin injections are minimized and hypoglycemia is also prevented. ${ }^{23}$ The side effects of islet cell transplantation are bleeding and blood clots moreover; the new islet cells in the patient body may function proper or not. On the other hand different medicines used by patient to minimize the transplant rejection have many side effects and this done during pancreas islet allo-transplantation but in case of pancreas auto-transplantation there is no need to take immunosuppressive medication.

\section{Role of gene therapy in the treatment of diabetes}

Gene therapy is a technique in which patient's faulty gene is removed by a healthy gene. Beta cells are used for the production of insulin and they are implanted into the patient's body now they produce sufficient amount of insulin to control the blood glucose level. But immunosuppressive drugs are needed to take by the patient. This procedure is used when glucose level rise in the blood and if it is not treated the patient may die.

\section{Transplantation of encapsulated islet cells}

Encapsulated islet cells are mainly used for the treatment of DM. This islet cell transplantation is under research and development. It is an advanced technique than insulin injection and pancreas transplantation. ${ }^{24}$ They are specific stem cells that are present in a capsule which protect the encapsulated islet cells. This capsule containing the encapsulated islet cells is then transplanted into the patient's body now the stem cells grow into cells and they are capable for the production of insulin as the main component and other hormones for other metabolic functions are also produced. The capsule of encapsulated islet cells has the advantage because it allows oxygen and other nutrients to enter the cells in this way the cells are feeded and capsule allow the insulin to leave out from the cell,

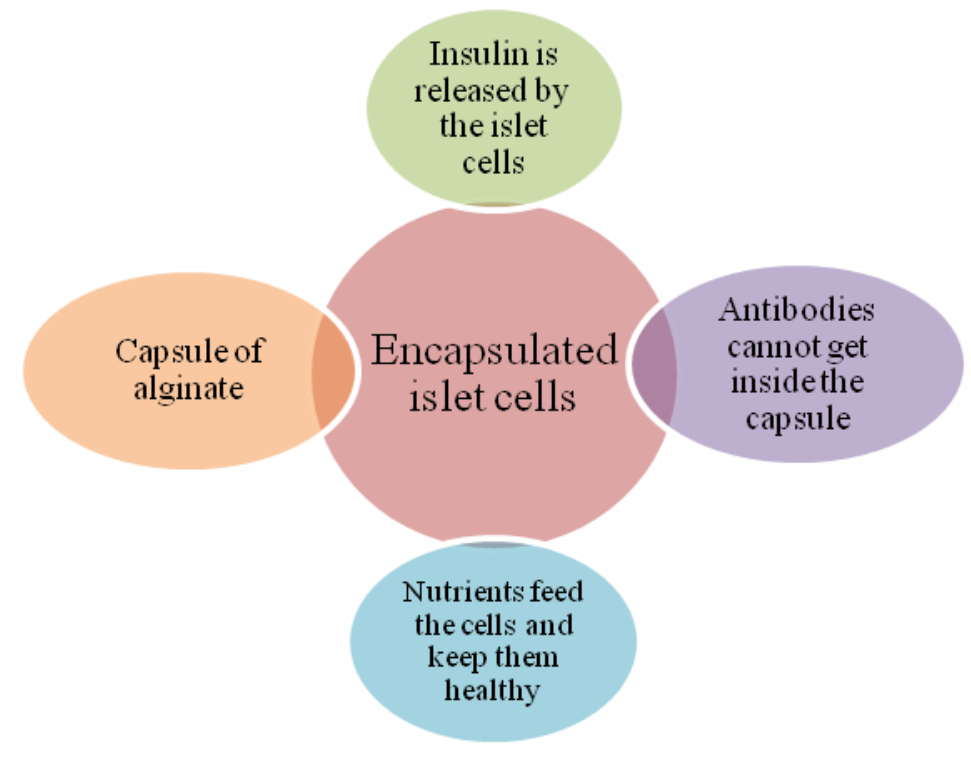

Fig: 2 Transplantation of encapsulated islet cells 
but it protect the cells because it does not allow white blood cells to enter the cells which are immune cells and kill the islet cells. In 1966, whole pancreas transplantation is conducted. Human islet cells are the best source for islet cell transplantation but it is limited by donor supplies, so the sources for islets should be improved. ${ }^{25}$

This technique has been investigated for many years to improve islet cell transplantation and to remove out side effects of immunosuppressive medications. Numerous encapsulated systems were used in the past, but microencapsulation is mostly studied. ${ }^{26}$ If the encapsulated islet cells are proved to work in humans then following benefits viz prevention from too high and too low sugar levels, elimination of taking insulin injections and prevention from daily glucose tests of blood. Encapsulated islet cell transplantation is not a cure but it is a treatment and diabetic patients face minimum management for many months. In maximum two years researchers are expected that encapsulated islet cell transplantation must be effective. In islet cell transplantation patient with type-1 diabetes must take strong immunosuppressive drugs to enhance the life of beta cells but autoimmune attack occur, so the patients with this transplantation again need to take insulin within a few months. ${ }^{27}$ The immunosuppressive drugs have other disadvantage that patient's ability of immune system to combat with hazardous infections is reduced. The major strength of encapsulation of islet cell transplantation is that no immunosuppressive drugs need to be taken. ${ }^{28}$ Description is shown in figure 2 .

\section{CONCLUSION}

Diabetes is a condition that causes high blood sugar levels. Pancreas is the main organ in which beta cells are present for the production of insulin. In $\mathrm{DM}$, no insulin is produced; and in DM cells do not respond to insulin. This disease is spread more rapidly in different countries but cases for type- 2 diabetes are mostly studied and obesity is the main problem for type-2 diabetes. Different techniques are being used to control blood glucose level. Although each technique has its own advantages and disadvantages but transplantation of encapsulated islet cells has been found better with respect to other techniques with minimum complications.

\section{REFERENCES}

1. Alarcon C, Boland BB, Uchizono Y, Moore PC, Peterson $\mathrm{B}$, Rajan S, et al. Pancreatic B-Cell Adaptive Plasticity in Obesity Increases Insulin Production but Adversely Affects Secretory Function. Diabetes. 2015; db150792.

2. Åvall K, Ali Y, Leibiger IB, Leibiger B, Moede T, Paschen M, Dicker A, Daré E, Köhler M, Ilegems E. Apolipoprotein CIII links islet insulin resistance to $\beta$-cell failure in diabetes. Proc. Natl. Acad. Sci. U.S.A. 2015;112: E2611E2619. https://doi.org/10.1073/pnas.1423849112. PMID: 25941406.

3. Babad J, Ali R, Schloss J, DiLorenzo TP. An HLATransgenic Mouse Model of Type 1 Diabetes That Incorporates the Reduced but Not Abolished Thymic Insulin Expression Seen in Patients. J Diabetes Res. 2015;501:842057.

4. Barnard KD, Pinsker JE, Oliver N, Astle A, Dassau E, Kerr D. Future artificial pancreas technology for type 1 diabetes: what do users want? Diabetes Technol. Ther. 2015;17:3115. https://doi.org/10.1089/dia.2014.0316. PMID: 25629627.

5. Chambers JC, Loh M, Lehne B, Drong A, Kriebel J, Motta V, Wahl S, Elliott HR, Rota F, Scott WR. Epigenome-wide association of DNA methylation markers in peripheral blood from Indian Asians and Europeans with incident type 2 diabetes: a nested case-control study. Lancet Diabetes Endocrinol. 2015;3:526-34. https://doi.org/10.1016/S22138587(15)00127-8

6. Eng C, Kramer CK, Zinman B, Retnakaran R. Glucagonlike peptide-1 receptor agonist and basal insulin combination treatment for the management of type 2 diabetes: a systematic review and meta-analysis. The Lancet. 2015;384:2228-34. https://doi.org/10.1016/S01406736(14)61335-0

7. Ghosi M, Abbasi F, Tootee A, Heshmat R, Rambod C, Larijani B. Insulin Independence after Fetal Liver-Derived Cell Suspension Allotransplantation in Patients with Type 1 Diabetes: A Pilot Study. Iran J Pub Health. 2015;44:27.

8. Jun LS, Millican RL, Hawkins ED, Konkol DL, Showalter $\mathrm{AD}$, Christe ME, et al. Absence of glucagon and insulin action reveals a role for the GLP-1 receptor in endogenous glucose production. Diabetes 2015;64:819-27. https:// doi.org/10.2337/db14-1052. PMID: 25288673.

9. Ahmad M, Mahmood Q, Gulzar K, Akhtar MS, Saleem M, Qadir MI. Antihyperlipidaemic and hepatoprotective activity of Dodonaea viscosa leaves extracts in alloxaninduced diabetic rabbits (Oryctolagus cuniculus). Paki Vet J. 2012;32:50-4

10. Ehsan O, Qadir MI, Malik SA, Abbassi WS, Ahmad B. Efficacy of nanogold-insulin as a hypoglycemic agent. J Chem Soc Pak. 2012;34:365-70.

11. Hussain A, Khalid SH, Qadir MI, Massud A, Ali M, Khan IU, et al. Water Uptake and Drug Release Behaviour of Methyl Methacrylate-co-itaconic acid [P(MMA/IA)]
[MAld Hydrogels Cross-linked with Methylene Bis-acrylamide. J Drug Deliv Sci Tech. 2011;21:249-55. https:// doi.org/10.1016/S1773-2247(11)50034-6

12. Iqbal MZ, Qadir MI, Mallhi TH, Khan YH, Ahmad B. Probiotics and their beneficial effects against various diseases. Pak J Pharm Sci. 2014;27:405-15. PMID: 24577933.

13. Janbaz KH, Hamid I, Gilani AH, Qadir MI. Spasmolytic, bronchodilator, and vasodilator activities of aqueousmethanolic extract of Ocimum basilicum. Int J Agric Biol. 2014;16:321-7.

14. Janbaz KH, Jan A, Qadir MI, Gilani AH. Spasmolytic, bronchodilator and vasorelaxant activity of methanolic extract of Tephrosia purpurea. Acta Pol Pharm. 2013;79:261-9.

15. Janbaz KH, Nisar U, Ashraf M, Qadir MI. Spasmolytic, bronchodilator and antioxidant activities of Erythrina superosa Roxb. Acta Pol Pharm. 2012;69:1111-7. PMID: 23285672.

16. Janbaz KH, Qadir MI, Jan A and Gilani AH. Anti-diarrheal 
activity of methanolic extract of Tephrosia purpurea. Acta Pol Pharm. 2013;79:345-7.

17. Javed F, Qadir MI, Janbaz KH, Ali M. Novel drugs from marine microorganisms. Cr Rev Microbiol. 2011;37:245-9. https://doi.org/10.3109/1040841X.2011.576234. PMID: 21599497.

18. Khalid SH, Qadir MI, Massud A, Ali M, Rasool MH. Effect of degree of cross-linking on swelling and drug release behaviour of poly (methyl methacrylate-co-itaconic acid) $[\mathrm{P}(\mathrm{MMA} / \mathrm{IA})]$ hydrogels for site specific drug delivery. J Drug Deliv Sci Tech. 2009; 19: 413-8. https:// doi.org/10.1016/S1773-2247(09)50085-8.

19. Masood MI, Qadir MI, Shirazi JH, Khan IU. Beneficial effects of lactic acid bacteria on human beings. Cr Rev Microbiol. 2011; 37: 91-98. https:// doi.org/10.3109/1040841X.2010.536522. PMID: 21162695.

20. Naz S, Qadir MI, Ali M, Janbaz KH. Nanotechnology for imaging and drug delivery in cancer. J Chem Soc Pak. 2011;34:107-11.

21. Nisa TU, Qadir MI, Malik SA. Effect of Eugenia jambolana leaves extracts on blood glucose levels of experimental diabetic rabbits. Pharmacologyonline. 2009;3:829-35.

22. Parveen A, Akash MSH, Rehman K, Mahmood Q, Qadir MI. Analgesic, anti-inflammatory and anti-pyretic activities of Caesalpinia decapetala. BioImpacts, 2014; 4: 43-48. PMID: 24790898.

23. Qadir MI, Malik SA. Anti-diabetic activity of inorganic metals Eugenia jambolana Lam. (Myrtaceae) flowers. Pharmacologyonline. 2010;2:979-85.

24. Qadir MI. Medicinal and cosmetological importance of Aloe vera. Int J Nat Ther. 2009;2:21-6.

25. Qadir MI. Medicinal values of ginger. Int $J$ Nat Ther. 2009;3:19-22.

26. Qadir MI. Qadirvirtide. Pak J Pharm Sci. 2011;24:593-5. PMID: 21959827

27. Saleem M, Qadir MI, Perveen N, Ahmad B, Saleem U, Irshad T, Ahmad B. Inhibitors of apoptotic proteins: New targets for anti-cancer therapy. Chem Biol Drug Desi. 2013;82:243-51. https://doi.org/10.1111/cbdd.12176. PMID: 23790005.

28. Qadir MI, Ali M, Malik SA, Abbas K, Arshad U, Ali M, et al. Effect of Eugenia jambolana Lam. (Myrtaceae) root extracts on blood glucose levels of experimental diabetic rabbits. Pak J Clin \& Biomed Res. 2013; 1: 32-36. 